\title{
Money Over Marriage: Marriage Importance as a Mediator Between Materialism and Marital Satisfaction
}

\author{
Ashley B. LeBaron \\ Brigham Young University - Provo \\ Heather H. Kelley \\ Brigham Young University - Provo \\ Jason S. Carroll \\ Brigham Young University - Provo, jcarroll@byu.edu
}

Follow this and additional works at: https://scholarsarchive.byu.edu/facpub

Part of the Other Social and Behavioral Sciences Commons

\section{Original Publication Citation}

LeBaron, A. B.*, Kelly, H. H.*, Carroll, J. S.(2018). Money Over Marriage: Marriage Importance as a Mediator Between Materialism and Marital Satisfaction. Journal of Family and Economic Issues, 39, 337-347.

\section{BYU ScholarsArchive Citation}

LeBaron, Ashley B.; Kelley, Heather H.; and Carroll, Jason S., "Money Over Marriage: Marriage Importance as a Mediator Between Materialism and Marital Satisfaction" (2017). Faculty Publications. 4370.

https://scholarsarchive.byu.edu/facpub/4370

This Peer-Reviewed Article is brought to you for free and open access by BYU ScholarsArchive. It has been accepted for inclusion in Faculty Publications by an authorized administrator of BYU ScholarsArchive. For more information, please contact ellen_amatangelo@byu.edu. 


\title{
Money Over Marriage: Marriage Importance as a Mediator Between Materialism and Marital Satisfaction
}

\author{
Ashley B. LeBaron ${ }^{1}\left[\right.$ ? Heather H. Kelley ${ }^{1}$ Jason S. Carroll ${ }^{1}$
}

Published online: 30 December 2017

๑) Springer Science+Business Media, LLC, part of Springer Nature 2017

\begin{abstract}
While the negative relationship between materialism and marital satisfaction is well documented, mediators that possibly explain this association have not been widely explored. Based on the Incompatibility of Materialism and Children Model and Marital Paradigms Theory, this article explores the perception of marriage importance as a potential mediator between materialism and marital satisfaction. Using a sample of 1310 married individuals, we found evidence of partial mediation in that materialism was negatively associated with perception of marriage importance, and this association partially explained why being materialistic was associated with lower marital satisfaction. Thus, as counselors, therapists, and financial planners work with married clients, it is important that they consider how their clients' materialistic tendencies may influence the family both financially and relationally. Suggestions for future research are discussed.
\end{abstract}

Keywords Family finance $\cdot$ Materialism $\cdot$ Financial therapy $\cdot$ Financial planning $\cdot$ Marital satisfaction $\cdot$ Marital centrality

\section{Introduction}

There is growing evidence that financial issues influence the quality and course of marriage relationships. For example, in a series of studies, Conger et al. (1990, 1994, 1999) showed that when spouses experienced economic hardship there were negative consequences at both the individual and couple level. Similarly, Gudmunson et al. (2007) found that financial strain was associated with negative interactions in marriage, including increased couple disagreements and decreased time together as a couple. More recently, financial conflict in marriage has been found to be a better predictor of divorce more than any other source of conflict (Dew et al. 2012). While studies such as these have repeatedly found a significant association between economic issues and marital outcomes, the mechanisms through which financial issues affect the quality of marriage are not well understood. Furthermore, little is known about what relationship characteristics might exacerbate or protect couples from the disruptive influence of economic problems (Conger et al. 1999).

Ashley B. LeBaron

lebaronashley@gmail.com

1 Brigham Young University, 2086 JFSB, Provo, UT 84602, USA
One contributor to financial conflict may be materialism (Dean et al. 2007), which has been defined as "the importance a consumer attaches to worldly possessions" (Belk 1984 , p. 291). In family finance research, materialism has thus far been viewed primarily as harmful to relationships (e.g., Dean et al. 2007; Li et al. 2015; Nickerson et al. 2003). Specifically, Dean et al. (2007) found that high levels of materialism increased the relative frequency with which couples perceived finances to be a problem in their relationship and that these increases were associated with lower levels of marital satisfaction for both husbands and wives. Carroll et al. (2011) further found that materialism had a negative association with marital quality, even when spouses were unified in their materialistic values. Specifically, they found that marriages in which both spouses reported low materialism were better off on several features of marital quality, including conflict resolution, problem areas, satisfaction, and stability, when compared to couples where one or both spouses reported high materialism.

In light of these findings, an important question is, "why does materialism negatively impact marriages?" While materialism may be a contributing factor to poor financial management behaviors that lead to debt and stain, financial factors may not be the only issue at play in these situations. Materialism is not an isolated life priority; as the pursuit of money and worldly possessions are prioritized, 
other dimensions of life are necessarily deemphasized. If the negative influence of materialism on marital satisfaction is as much about competing values and relational behavior as it is about financial attitudes, then the way scholars think about and approach materialism may need to change. This article explores the perception of marriage importance as a potential mediator between materialism and marital satisfaction. The overarching purpose of this study is to extend our understanding of the specific mechanisms that explain how materialism influences marriage relationships.

\section{Literature Review}

\section{Materialism and Marital Satisfaction}

Financial stressors and conflict are negatively associated with marital satisfaction (Archuleta et al. 2011; Conger et al. 1999; Dew 2011; Gudmunson et al. 2007) and even predict divorce (Albrecht 1979; Amato and Rogers 1997; Dew et al. 2012; cf. Andersen 2005). Financial issues can clearly have a negative impact on marriage relationships, and materialism has begun to be researched as an element of this relationship (Dean et al. 2007). Materialism may be an ever increasingly relevant issue for developed, consumer-focused societies (Li et al. 2015). It has become an important topic for family researchers because it seems to negatively impact not only personal financial wellbeing (Garðarsdóttir and Dittmar 2012; Watson 2003), but also relationship wellbeing (Kashdan and Breen 2007), including marital satisfaction (Dean et al. 2007). Materialism has also been linked to less satisfaction with life in general (Richins and Dawson 1992), as well as more negative attitudes toward marriage and family (Li et al. 2015). These associations may give insight into the negative relationship between materialism and marital satisfaction. However, research has yet to identify why this relationship exists.

\section{Perception of Marriage Importance as a Mediator}

The perception of marriage importance is a potential explanation for the relationship between materialism and marital satisfaction. The theoretical rationale for the idea that the perception of marriage importance may be a mediator of this relationship stems from two theoretical frameworks: The Incompatibility of Materialism and Children Model (IMC, Li et al. 2011, 2015) and Marital Paradigms Theory (Willoughby et al. 2015b). The IMC Model explains why higher materialism may be related to lower perception of marriage importance, and Marital Paradigms Theory explains why lower perception of marriage importance may then be related to lower marital satisfaction.

\section{The Incompatibility of Materialism and Children Model}

The IMC Model (Li et al. 2011, 2015) states that materialism predicts negative attitudes toward marriage and having children. This hypothesis stems from the observation that when countries have greater wealth they tend to have a greater average number of children per family (Lee 2003), yet large differences in average number of children exist among countries of similar wealth (Country Comparison: GDP-Per capita (PPP) 2009; Country Comparison: Total Fertility Rate 2009). Li et al. (2015) developed this model while they examined concerns that the fertility rates in Eastern Asian countries were not at replacement levels. The original IMC model (2011) depicted that life satisfaction predicted attitudes toward marriage, both directly and through materialism, and that attitudes toward marriage then predict desires for children. In this study, "attitude toward marriage" was measured as one's personal desire to get married and the amount of happiness they felt they would derive from getting married. In the modified IMC model ( $\mathrm{Li}$ et al. 2015), materialistic values were predicted to influence attitudes toward marriage and family, which predict attitudes toward having children and the number of children desired. Findings from studies support these propositions ( $\mathrm{Li}$ et al. 2011, 2015).

$\mathrm{Li}$ et al. theorized that the more time and effort one exerts in the pursuit of money and material things, the less time and effort can be dedicated to other values (Myers 1999; Solberg et al. 2004). Additionally, there seems to be something about materialism that is not conducive to quality family relationships. Specifically, high materialism has been linked with less likelihood of having and prioritizing close relationships (Burroughs and Rindfleisch 2002; Kasser et al. 2007), less likelihood of prioritizing relational warmth (Richins and Dawson 1992), greater number of conflicts within close relationships (Kasser and Ryan 2001), greater avoidance of intimacy (Kasser and Grow Kasser 2001), and less satisfaction with family life (Nickerson et al. 2003). These findings seem to suggest that materialism is a value which must compete with marriage and family for time and attention ( $\mathrm{Li}$ et al. 2011, 2015).

\section{Marital Paradigms Theory}

According to Marital Paradigms Theory (MPT, Willoughby et al. 2015b), how individuals view marriage impacts how they behave in marriage relationships. The theory encompasses beliefs related to both getting married and being married. Beliefs about getting married are categorized into marital timing, marital salience, and marital context, while beliefs about being married are categorized into marital processes, marital permanence, and marital centrality. This study draws specifically upon 
marital centrality, which is the importance one places on their marriage relative to other facets of their life (Willoughby et al. 2015b). Marital centrality has such an impact because the importance one places on marriage affects how one prioritizes their marriage relative to other domains. The theory suggests three specific domains that may compete with one's prioritization of their marriage: work, leisure, and parenting (Willoughby et al. 2015a). The pursuit of money and material things could be related to both work (prioritizing making money) and leisure (prioritizing the enjoyment of material things); therefore, materialism could compete with the priority one places on their marriage.

As other goals are given higher priority than marital centrality, marital behaviors and subsequent marital satisfaction may be put at risk. Because marital centrality is, unfortunately, the most understudied of the six dimensions of MPT (Willoughby et al. 2015b) and because the theory is very new, almost no research has been conducted linking marital centrality to specific behavioral outcomes. However, one study by Willoughby et al. (2015a) found that higher levels of marital centrality predicted less engagement in risky behaviors in young adults. Additionally, general findings related to marital beliefs have found that these beliefs impact daily decision-making (Willoughby et al. $2015 \mathrm{~b}, \mathrm{c})$. The theory proposes that not only do these links exist, but that the relationships may be reciprocal. Marital beliefs influence behaviors, and one's experience in relationships and marriage in turn influences beliefs (Willoughby et al. 2015c). For example, cohabiting has been found to diminish marital centrality in emerging adults (Willoughby et al. 2015c).

Based on this assumption, it makes sense that a diminished perception of marriage importance would predict lower marital satisfaction given that behaviors in marriage are inextricably tied to marital satisfaction (Gottman and Krokoff 1989). Things, including relationships, become more meaningful to people the more they invest in them. For example, the more time, effort, and resources one invests in a relationship, the higher the level of satisfaction one feels towards the relationship (Rusbult 1980). Thus, when one values one's marriage less, one may be less likely to put forth the love and effort necessary for high marital satisfaction. Additionally, marital centrality is a similar measure to marital commitment (Owen et al. 2011; Stanley and Markman 1992; Willoughby et al. 2015a), which has been established as a predictor of marital satisfaction (Stanley et al. 2002). This further supports the notion that perception of marriage importance would be associated with marital satisfaction.

\section{Current Study}

In summary, previous literature has established the negative relationship between materialism and marital satisfaction. However, no study we have found has examined perception of marriage importance as a mediator between materialism and marital satisfaction. The current study was designed to explore this potential mediation in order to better understand the negative relationship between materialism and marital satisfaction. The guiding theoretical premise of our analysis was that materialism is a value which must compete with one's marriage for time and attention ( $\mathrm{Li}$ et al. 2015, 2011) and which seems to decrease desire for and prioritizing of close relationships (Burroughs and Rindfleisch 2002; Kasser et al. 2007). As materialism is given higher priority than marriage, marital behaviors and subsequent feelings about the marriage may become increasingly negative (Willoughby et al. 2015b, c). Taken together, these theoretical propositions suggest that higher materialism may lead to lower perception of marriage importance, which may in turn lead to lower marital satisfaction.

For the purposes of this study, we focused specifically on the portion of the models that portray greater materialism predicting negative attitudes toward marriage. While $\mathrm{Li}$ et al.'s (2015) "attitude toward marriage" construct (attitude toward one's own future marriage) differs slightly from our "importance of marriage" construct (attitude toward both the institution of marriage and one's own current marriage), we believe the two are likely very related and thus relevant. Also, as per related literature, we controlled for gender and income (e.g., Archuleta et al. 2011; Dean et al. 2007) as well as age (Gudmunson et al. 2007; Li et al. 2015).

Based on previous research and these two theoretical frameworks, we offer two hypotheses:

Hypothesis 1 Materialism will be negatively associated with perception of marriage importance.

Hypothesis 2 Perception of marriage importance will mediate the negative relationship between materialism and marital satisfaction.

\section{Methods}

\section{Participants}

The sample for this study was selected from an ongoing study of marital and premarital relationships sponsored by the RELATE Institute. Founded in 1979, the RELATE Institute is a national non-profit consortium of researchers, clinicians, and family life educators who are committed to understanding and strengthening intimate relationships. 
Since the creation of the RELATionship Evaluation Questionnaire (RELATE; Holman et al. 1997), tens of thousands of individuals and couples have completed the survey.

A sample of 1310 married individuals was selected from the respondents who completed RELATE between 2006 and 2011. Because our foundation theories state assumptions about married people specifically, we included only married participants in our analyses. Our dataset contained individual responses, not dyadic data. Thus, analyses were conducted on the individual level. The sample was $63.4 \%$ female and $36.4 \%$ male. The average age of the sample was 35.5 years $(\mathrm{SD}=9.6)$. The largest religious denomination within the sample was Protestant (35.1\%) followed by no religious affiliation $(21.8 \%)$ and Catholic (20.2\%). One-third $(32.9 \%)$ of the sample had been married for 2 years or less, $35.8 \%$ had been married between 3 and 10 years, and the remaining $31.2 \%$ had been married for more than 10 years. Almost one-third $(29.1 \%)$ of the sample reported a yearly personal income of less than $\$ 20,000$, while $34.5 \%$ reported between $\$ 20,000$ and $\$ 59,999$, and $36.4 \%$ reported $\$ 60,000$ or more. ${ }^{1}$

\section{Procedure}

The RELATionship Evaluation (RELATE) assessment is a couple assessment designed to assess and provide feedback to those in romantic relationships. All participants completed an appropriate consent form prior to the completion of the RELATE instrument and all data collection procedures were approved by the institutional review board at the authors' university. Participants completed RELATE online individually, after which couples were provided with feedback on their relationship strengths and weaknesses. For this study, we used only individual responses, not paired couple responses. Some participants were referred to the online site by their instructor in a university class, others by a relationship educator or therapist, and some participants found the instrument by searching for it on the web. See Busby et al.'s (2001) discussion of RELATE for detailed information regarding the theory underlying the instrument and its psychometric properties.

\section{Measures}

This study employed items and scales from the RELATE dataset to measure materialism, perception of marriage importance, and marital satisfaction (Busby et al. 2001). We also controlled for gender, income, and age. Gender was

\footnotetext{
${ }^{1}$ Dollar values are in US currency.
}

dichotomized as male (0) and female (1). Income was ordinal, measured from low to high.

\section{Materialism}

To measure materialism, we used the item "Having nice things today is more important to me than saving for the future." The item was measured on a Likert scale, ranging from 1 (Strongly Disagree) to 5 (Strongly Agree). Higher scores measure higher materialism. Although RELATE contains The Importance of Money and Material Things scale $(\alpha=.24)$, Cronbach's alpha was unacceptably low. The scale is composed of only two items (the other being "Husbands and wives should both carefully look for bargains before buying something they want.”). Thus, we employed the item we deemed more closely measures materialism.

\section{Perception of Marriage Importance}

The Importance of Marriage scale $(\alpha=.717)$ was used to measure perception of marriage importance. The scale is composed of four items, including "Being married is among the one or two most important things in life." and "If I had an unhappy marriage and neither counseling nor other actions helped, my spouse and I would be better off if we divorced." All items were measured on a Likert scale, ranging from 1 (Strongly Disagree) to 5 (Strongly Agree). Two of the items were reverse coded so that, for all items, higher scores measure higher perception of marriage importance.

\section{Marital Satisfaction}

Participants' marital satisfaction was measured using the Relationship Satisfaction scale $(\alpha=.92)$. The scale is composed of seven items, including "The physical intimacy you experience" and "How conflicts are resolved," measured on a Likert scale, ranging from 1 (Very Dissatisfied) to 5 (Very Satisfied). Higher scores measure higher marital satisfaction.

\section{Results}

\section{Descriptive Results}

Descriptive statistics for all study variables are presented in Table 1. Responses for the materialism item included the full range (1-5), but the mean response tended towards lower levels of materialism $(M=2.15, S D=.82)$. For the Importance of Marriage scale $(\alpha=.72)$, responses to which also included the full range (4-20), the mean response tended towards higher perceived importance $(M=13.550$, $S D=3.7)$. Responses to the Marital Satisfaction scale 
Table 1 Descriptive statistics of the sample

\begin{tabular}{lrll}
\hline Variables & $M$ & $S D$ & Range \\
\hline Materialism & 2.150 & .820 & $1-5$ \\
Perception of marriage & 13.550 & 3.703 & $4-20$ \\
$\quad$ importance & & & \\
Marital satisfaction & 23.658 & 6.996 & $7-35$ \\
Gender & .634 & .482 & $0-1$ \\
Income & 3.260 & 2.738 & $0-11$ \\
Age & 35.510 & 9.555 & $18-71$ \\
\hline
\end{tabular}

Because data on income was ordinal in nature, exact descriptive statistics were impossible to obtain. For this variable, descriptive statistics are based on category responses

( $\alpha=.92$ ) also included the full range of possible responses (7-35) and tended toward higher marital satisfaction $(M=23.658, S D=7.0)$. Complete descriptive results can be found in Table 1 .

\section{Bivariate Correlations}

Pearson correlation coefficients were then run as preliminary statistics. As shown in Table 2, materialism was negatively associated with both perception of marriage importance $(r=-.173, p<.001)$ and marital satisfaction $(r=-.079$, $p=.004)$, and importance of marriage was positively correlated with marital satisfaction $(r=.156, p<.001)$. Because gender was not significantly correlated with either outcome variable, it was excluded from further analyses. For complete bivariate correlations, see Table 2.

\section{Measurement Model}

First, a measurement model was conducted using structural equation modeling with AMOS software. Latent variables were created for perceived importance of marriage and marital satisfaction, with all factor loadings above .500 with the exception of one factor under perception of marriage importance which loaded at .395. Because this is so close to the standard cutoff of .4 , we deemed it acceptable and chose to retain the item. See Table 3 for all factor loadings. Acceptable model fit was based on Little's (2013) criteria of CFI $>.900$ and a RMSEA $<.080$. One modification was made between error variances of marital satisfaction items in order to achieve better model fit. Model fit suggested that the model fit the data well, $\chi^{2}(42)=180.079, p<.001$, $\mathrm{CFI}=.983$, RMSEA $=.050$.
Table 2 Preliminary correlations among variables

Table 3 Factor loadings for latent variables

\begin{tabular}{lllllll}
\hline & 1 & 2 & 3 & 4 & 5 & 6 \\
\hline 1. Materialism & - & & & & & \\
2. Importance of marriage & $-.173^{* * *}$ & - & & & & \\
3. Marital satisfaction & $-.079^{* *}$ & $.156^{* * *}$ & - & & & \\
4. Gender & $-.085^{* *}$ & -.010 & -.019 & - & & \\
5. Income & .014 & $-.143^{* * *}$ & $-.080^{* *}$ & $-.311^{* * *}$ & - & \\
6. Age & -.045 & -.008 & $-.186^{* * *}$ & $-.118^{* * *}$ & $.306^{* * *}$ & - \\
\hline
\end{tabular}

$* p<.05, * * p<.01, * * * p<.001$

Items

Importance of Marriage

Being married is among the one or two most important things in life .395

If I had an unhappy marriage and neither counseling nor other actions helped, my spouse and I $\quad .559$ would be better off if we divorced

Marriage involves a covenant with God, not just a legal contract recognized by the law $\quad .764$

Living together is an acceptable alternative to marriage .779

Relationship Satisfaction-In your relationship, how satisfied are you with the following?

The physical intimacy you experience .695

The love you experience .903

How conflicts are resolved $\quad .750$

The amount of relationship equality you experience .842

The amount of time you have together .595

The quality of your communication $\quad .792$

Your overall relationship with your partner .930 
Fig. 1 Correlations and standardized direct effects. Endogenous error correlations, modification indices, and factor loadings are not shown for parsimony. Standardized correlations and weights are shown. ${ }^{*} p<.05, * * p<.01, * * * p<.001$

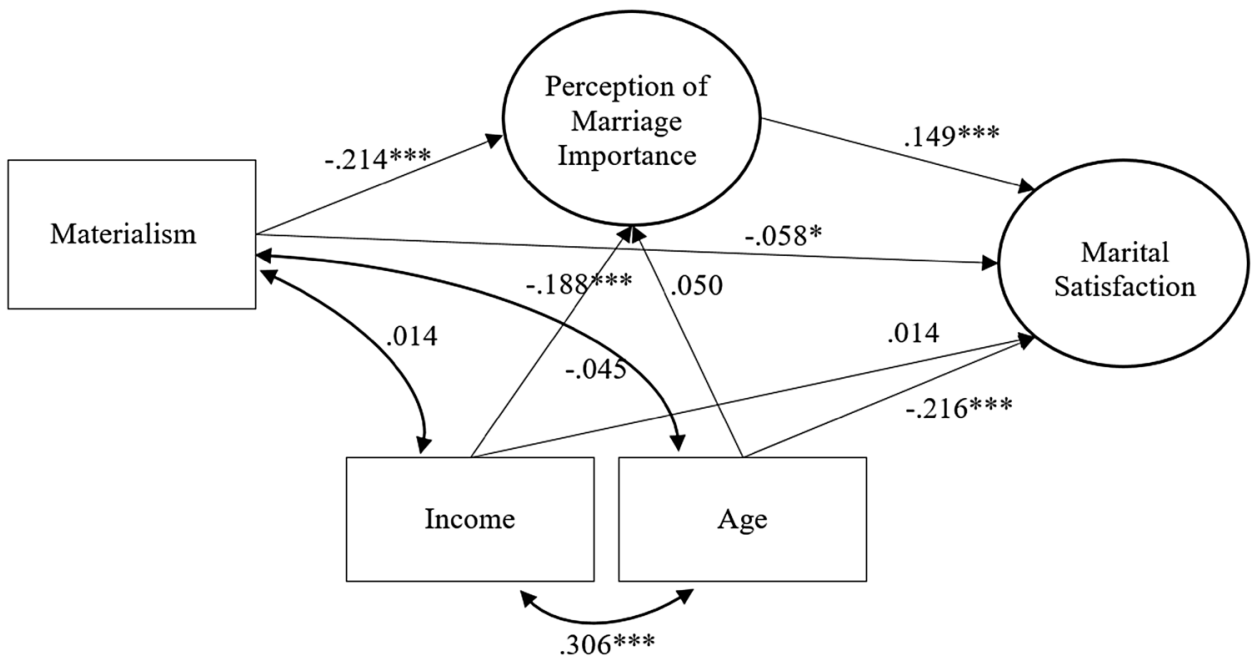

\section{Structural Model}

A structural model was conducted with materialism predicting perception of marriage importance and marital satisfaction. Perception of marriage importance, in turn, predicted marital satisfaction. The current model examined perception of marriage importance as a mediator of the relationship between materialism and marital satisfaction. Thus, both direct and indirect paths were explored. Income and age were used as controls based on preliminary correlations. They were correlated with each other as well as with materialism. Additionally, direct paths were included from income and age to perception of marriage importance, as well as to marital satisfaction. All correlations and paths can be seen in Fig. 1. Final model fit suggested that the model fit the data well, $\chi^{2}(69)=264.852, p<.001$, $\mathrm{CFI}=.977$, RMSEA $=.047$. The $\chi^{2}$ may have been significant and therefore not acceptable because of the large sample $(N=1310)$. The model predicted approximately $7 \%$ of the variance in marital satisfaction $\left(\mathrm{R}^{2}=.072\right)$ and $8 \%$ of the variance in perception of marriage importance $\left(\mathrm{R}^{2}=.080\right)$.

Analyses of direct effects suggested that higher materialism significantly predicted lower perception of marriage importance $(\beta=-.214, p<.001)$ and lower marital satisfaction $(\beta=-.058, p=.042)$. Lower perception of marriage importance significantly predicted lower marital satisfaction $(\beta=.149, p<.001)$. Additionally, higher income significantly predicted lower perception of marriage importance ( $\beta=-.188, p<.001)$ but did not significantly predict marital satisfaction ( $\beta=.014, p=.635)$. On the other hand, age did not significantly predict perception of marriage importance $(\beta=.050, \mathrm{p}=.121)$, but greater age predicted lower marital satisfaction $(\beta=-.216, p<.001)$.

To test the indirect effect, 2000 bootstraps were performed at a 95\% confidence interval. Analyses revealed a significant indirect effect via perception of marriage importance between materialism and marital satisfaction (standardized indirect effect $=-.032, \mathrm{CI}=-.052--.016$, $p<.001)$. Due to the significant indirect effect and the remaining direct effect between materialism and marital satisfaction, we concluded that perception of marriage importance partially mediated the negative relationship between materialism and marital satisfaction.

\section{Sensitivity Analysis}

Although causality cannot be determined empirically using cross-sectional data, we conducted a follow-up sensitivity analysis in order to explore potential simultaneity and endogeneity issues between importance of marriage and marital satisfaction. It may be possible that marital satisfaction predicts importance of marriage because, according to MPT, one's experience in marriage can influence one's beliefs about marriage (Willoughby et al. 2015c). One way to test for this in SEM is to use a nonrecursive model with a direct feedback loop and correlated disturbances (Kline 2016). This means that regression paths were drawn in both directions between importance of marriage and marital satisfaction, thus creating a direct feedback loop which allows us to compare the relative strength of each path and determine any predominant directionality (Kline 2016). The error terms of importance of marriage and marital satisfaction were correlated in a bow-pattern disturbance correlation (see Kline 2016).

Additionally, income was used as an instrumental variable for importance of marriage, while age was used as an instrumental variable for marital satisfaction. These were deemed adequate instruments because in the study's main structural model (Fig. 1), they were significantly associated with their respective endogenous variable and not with the other (Kline 2016). Intuitively, income may 


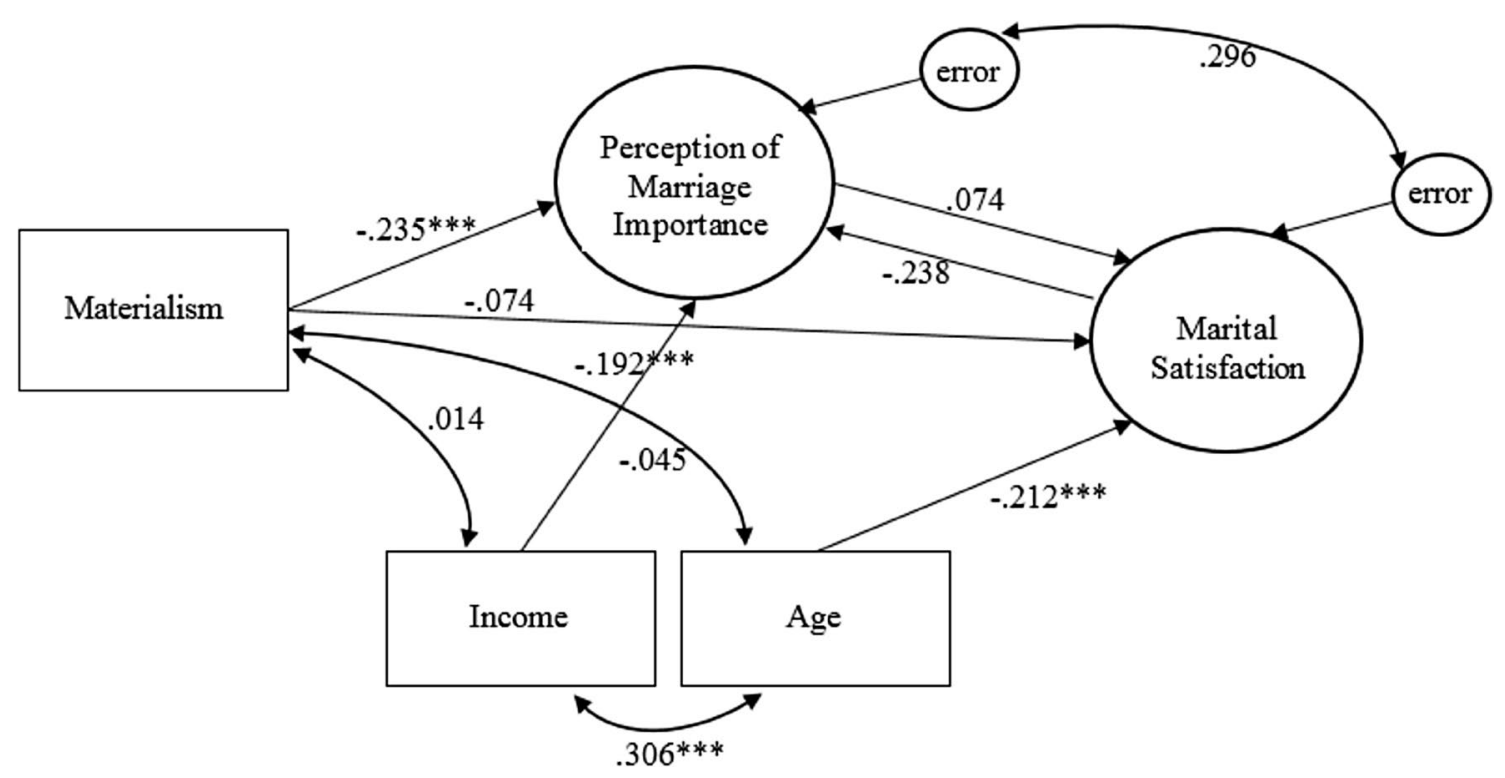

Fig. 2 Correlations and standardized direct effects. Modification indices and factor loadings are not shown for parsimony. Standardized correlations and weights are shown. ${ }^{*} p<.05, * * p<.01, * * * p<.001$

be related to perception of marriage importance because marriage is economically beneficial and may be especially important to those with lower incomes (Thomas and Sawhill 2005), while age may be related to marital satisfaction because marital satisfaction tends to decline over time (VanLaningham et al. 2001). Thus, in the nonrecursive model, regression paths were drawn from the instruments to their respective endogenous variable, as well as from materialism to both endogenous variables. All correlations and paths can be seen in Fig. 2. The equations for these models are

$$
\begin{aligned}
& \text { Marital Satisfaction }_{i}=\text { Intercept }_{i}+\text { Materialism }_{i} \\
& + \text { Marriage Importance }_{i}+\text { Age }_{i}+e
\end{aligned}
$$

$$
\text { Marriage Importance }_{i}=\text { Intercept }_{i}+\text { Materialism }_{i}
$$

$$
+ \text { Marital Satisfaction }_{i}+\text { Income }_{i}+e
$$

Results showed no predominant effect between importance of marriage and marital satisfaction (importance of marriage to marital satisfaction: $\beta=.074, p=.629$; marital satisfaction to importance of marriage: $\beta=-.238, p=.140$ ). Because neither path was significant, any purported causal direction must rely on theoretical claims. However, the error terms of the two endogenous variables were not significantly correlated $(r=.296, p=.156)$, suggesting no simultaneity issues. While it is possible that marital satisfaction may predict importance of marriage, this was not apparent in our data.

\section{Discussion}

The current study tested whether spouses' perceptions of marriage importance mediated the relationship between materialism and marital satisfaction. Results supported our first hypothesis, namely that materialism would be negatively associated with perception of marriage importance. Our second hypothesis was somewhat supported which proposed that perception of marriage importance would mediate the negative relationship between materialism and marital satisfaction. Specifically, the results suggest that being materialistic, or placing high importance on money and material things, is associated with placing a lower importance on marriage. Additionally, the importance of marriage partially mediated the relationship materialism and marital satisfaction, suggesting that at least part of the reason why placing high value on money is correlated with lower marital satisfaction is because placing high value on money is associated with placing a lower value on marriage, which in turn relates to lower marital satisfaction.

Our study contributes to the small but growing body of research that finds a negative association between materialism and attitude toward marriage (e.g., Burroughs and Rindfleisch 2002; Kasser et al. 2007; Kasser and Grow Kasser 2001; Nickerson et al. 2003). As expected in our first hypothesis, it seems as though placing great importance on money and material things can compete with or hinder the importance one places on marriage. Why this is the case deserves further investigation and study. One possibility is that materialism crowds out other life priorities and creates a scarcity of time for other priorities such as giving time 
to relationship processes such as communication, conflict resolution, and intimacy. In short, as the pursuit of money and worldly possessions are prioritized, other dimensions of life are necessarily deemphasized. Another possibility is that materialism is associated with a life orientation that is qualitatively different than than relationship-centered paradigms. This may be because materialism is inherently selfish and related to gain, and seems to be in opposition to qualities such as selflessness and giving that tend to engender feelings of intimacy and commitment (Impett et al. 2013; Van Lange et al. 1997a, b; Wieselquist et al. 1999). Indeed, previous research has found that being materialistic predicts being competitive and self-centered (Bauer et al. 2012).

Carroll et al. (2011; Dean et al. 2007) explained these associations by pointing out that "materialism is one reflection of an individualistic paradigm that permeates Western culture" (p. 246). Referring to Bellah's (1996) concepts of utilitarian and expressive individualism, they suggested that "materialistic individualism" is a form of utilitarian individualism and stands in contrast to a more expressive or communal orientation to life. They explained that "for the classic utilitarian individualist, the only valid social contract is one based on negotiation between individuals acting in their own self-interest...in contrast, individuals with a familial or communal orientation will sacrifice their own comforts for the betterment of the group" (p. 246).

The results were also aligned with Marital Paradigms Theory, which states that how one views their marriage will impact how they behave in that marriage (Willoughby et al. 2015b). Based on our results, it seems as though lower perception of marriage importance may stifle behaviors that generate high marital satisfaction and/or breed behaviors that generate low satisfaction. While the theory proposes that perception of marriage influences behaviors in marriage, our study used marital satisfaction as the outcome variable. While future research should use behaviors as outcome variables, we believe that behaviors within marriage are inextricably linked to marital satisfaction (Gottman and Krokoff 1989). Further research is needed to determine the specific behaviors and pathways at play in the relationship between perception of marriage importance and marital satisfaction (Willoughby et al. 2015b). While our findings investigate perception of marriage importance specifically, future research should investigate the impact of materialism on other facets of attitude toward marriage and having children.

Although not a specific focus of our study, an unexpected but noteworthy finding emerged in regards to the association between income and marital satisfaction. While income had a significant negative association with marital satisfaction in bivariate correlations, that association became nonsignificant in the final SEM. However, the association between income and perceived importance of marriage remained. This suggests that perceived importance of marriage may be a potential mediator between income and marital satisfaction. Perhaps higher income engenders lower perceptions of the importance of marriage, thereby lowering marital satisfaction. Future research should investigate this phenomenon.

\section{Implications}

There are many implications of these findings, particularly for financial counselors, financial therapists, marriage and family therapists, social workers, and financial planners. Given that married people tend to have greater financial wellbeing (Doherty et al. 2002; Waite and Gallagher 2000), clients' marital satisfaction and how it is affected by materialism should be one of the priorities of the counselors, therapists, and financial planners. In addition, the very definition of materialism alludes to unhealthy financial behaviors such as compulsive spending and delayed saving. As counselors, therapists, and financial planners work with married clients of varying demographic backgrounds and financial situations, it is important that they gage how materialistic the clients are and recognize how that may impact the family both financially and relationally. If the clients seem to have high levels of materialism, counselors, therapists, and financial planners should help clients adopt lower levels of materialism and/or help clients build a strong perception of the importance of marriage and family. Given that marital beliefs have been shown to be dynamic (Willoughby et al. 2015c), it seems probable that clinicians could play a key role in shaping their clients' marital centrality. We extend a call for future research dedicated to the unique intricacies of working with materialistic clients in a clinical setting.

All that being said, many couples never seek help from a counselor or therapist. In order to preserve marital satisfaction, people with high levels of materialism should be especially cognizant of how they prioritize their marriage relative to other facets of life, including money and material things. Awareness may empower individuals to combat the potential negative effects of their materialistic tendencies. Outreach efforts and policies can assist by spreading awareness of these potential effects and by striving to increase perception of the importance of marriage on a societal and community level.

\section{Limitations and Future Research}

The current study is one of the first explorations of potentiation between materialism and marital satisfaction and the first, to our knowledge, that has investigated perception of marriage importance as a mediator in this relationship. 
Additionally, we employed a large sample. Although the study had notable strengths, it also had limitations. The study was cross-sectional; accordingly, future research should examine this mediation longitudinally to explore the relationships over time. While partial mediation was found, it was a relatively small effect. There are likely other factors involved in the relationship between materialism and marital satisfaction beyond perception of marriage importance, and these factors are worth exploring in future research. Based on previous research, potential mediators include financial conflict (Dew et al. 2012), a mismatch in financial attitudes (Britt et al. 2016), debt and lack of savings (Garðarsdóttir and Dittmar 2012; Watson 2003), and life satisfaction (Richins and Dawson 1992).

Additionally, our sensitivity analysis could not support the purported causal direction of our model. While our model was constructed based on the IMC Model (Li et al. 2011, 2015) and MPT (Willoughby et al. 2015b), other models may be relevant based on other theories; for example, it is possible that perception of marriage importance is a predictor of materialism in addition to materialism predicting perception of marriage importance. Also, although our sensitivity analysis did not indicate this, perception of marriage may predict marital satisfaction. Future research should examine these potential models.

Finally, there are limits to our measures. The importance of marriage scale we utilized seems to capture attitude toward both the institution of marriage and the permanence of one's own marriage. These concepts may not completely parallel marital centrality as put forth by MPT (Willoughby et al. 2015b). The findings should be interpreted with these limitations in mind. Additionally, materialism was measured using a single item; future research should employ a more complete measure of materialism, such as Richins and Dawson's (1992) threepronged, values-oriented materialism measure. This measure of materialism is especially noteworthy because it accounts for three dimensions of materialism: centrality, happiness, and success. Acquisition centrality is the extent to which money and material things are central to one's life, while acquisition as the pursuit of happiness is the extent to which one believes that money and material things are essential for satisfaction and fulfillment in life, and possession-defined success is the extent to which one believes that success in life is based on one's money and possessions compared to others'. Although we found perception of marriage importance to be a relatively small mediator between our measure of materialism and marital satisfaction, it could be that the indirect effect may be different when using a materialism scale such as Richins and Dawson's (1992). Specifically, the centrality subscale of materialism would be particularly interesting to employ because it juxtaposes so well with marital centrality.
Future research could test perception of marriage importance as a mediator between materialism and marital satisfaction using the three dimensions of materialism (Richins and Dawson 1992) as separate independent variables for the purposes of using a more complete measure but also to test for differences by types of materialistic values.

\section{Conclusion}

Our study found that perceived importance of marriage partially mediated the negative relationship between materialism and marital satisfaction. It seems as though the influence of materialism on marital satisfaction is not solely about financial attitudes but can be further explained by competing values and relational behavior. This study is an important stepping stone for researchers in expanding our understanding of the negative impact materialism can have on marital satisfaction. Our findings suggest that it may be important for clinicians to gauge how materialistic their clients are and recognize potential relational effects. If the clients seem to have high levels of materialism, counselors, therapists, and financial planners should help clients adopt lower levels of materialism and/or help clients build a strong perception of the importance of marriage and family. Additionally, because awareness may empower individuals to combat the potential negative effects of materialism, those involved with outreach and policy can assist by spreading awareness of these potential effects and by striving to increase perception of the importance of marriage on a societal and community level. As future research builds on this knowledge, the intricate connections between finances and marriage will continue to unfold.

Acknowledgements We would like to thank Dr. Sarah Coyne, Dr. Brian Willoughby, and Nathan Leonhardt for their helpful reviews of earlier drafts. We would like to thank Dr. Jeremy Yorgason, Dr. Joseph Olsen, and Dr. Spencer James for their statistical counsel. Finally, we would like to thank Dr. Jeff Hill and Dr. Loren Marks for their encouragement and support.

Funding No funding was received for this study.

\section{Compliance with Ethical Standards}

Conflict of interest Ashley LeBaron declares that she has no conflict of interest. Heather Kelley declares that she has no conflict of interest. Jason Carroll declares that he has no conflict of interest.

Ethical Approval All procedures performed in studies involving human participants were in accordance with the ethical standards of the institutional and/or national research committee and with the 1964 Helsinki declaration and its later amendments or comparable ethical standards. This article does not contain any studies with animals performed by any of the authors. 
Informed Consent Informed consent was obtained from all individual participants included in the study.

\section{References}

Albrecht, S. L. (1979). Correlates of marital happiness among the remarried. Journal of Marriage and Family, 41(4), 857-867. https://doi.org/10.2307/351485.

Amato, P. R., \& Rogers, S. J. (1997). A longitudinal study of marital problems and subsequent divorce. Journal of Marriage and Family, 59(3), 612-624. https://doi.org/10.2307/353949.

Andersen, J. D. (2005). Financial problems and divorce: Do demographic characteristics strengthen the relationship? Journal of Divorce \& Remarriage, 43(1-2), 149-161. https://doi. org/10.1300/J087v43n01_08.

Archuleta, K. L., Britt, S. L., Tonn, T. J., \& Grable, J. E. (2011). Financial satisfaction and financial stressors in marital satisfaction. Psychological Reports, 108(2), 563-576. https://doi. org/10.2466/07.21.PR0.108.2.563-576.

Bauer, M. A., Wilkie, J. B., Kim, J. K., \& Bodenhausen, G. V. (2012). Cuing consumerism: Situational materialism undermines personal and social well-being. Psychological Science, 23(5), 517-523. https://doi.org/10.1177/0956797611429579.

Belk, R. W. (1984). Three scales to measure constructs related to materialism: Reliability, validity, and relationships to other measures of happiness. In T. Kinnear (Ed.), Advances in consumer research (Vol. 11, pp. 291-297). Provo, UT: Association for Consumer Research. Retrieved from http://www.acrwebsite.org/ volumes/6260/volumes/v11/NA-11.

Bellah, R. N. (1996). Habits of the heart: Individualism and commitment in American life. Berkeley: University of California Press.

Britt, S., Hill, E. J., LeBaron, A. B., \& Bean, R. (2016). Savers and spenders: Predicting financial conflict in couple relationships. Paper presented at the annual conference of the Financial Planning Association to be held in Baltimore, MD.

Burroughs, J. E., \& Rindfleisch, A. (2002). Materialism and well-being: A conflicting values perspective. Journal of Consumer Research, 29, 348-370. Retrieved from https://academic.oup.com/jcr/.

Busby, D. M., Holman, T. B., \& Taniguchi, N. (2001). RELATE: Relationship evaluation of the individual, family, cultural, and couple contexts. Family Relations, 50(4), 308-316. https://doi. org/10.1111/j.1741-3729.2001.00308.x.

Carroll, J. S., Dean, L. R., Call, L. L., \& Busby, D. M. (2011). Materialism and marriage: Couple profiles of congruent and incongruent spouses.Journal of Couple \& Relationship Therapy, 10(4), 287-308. Retrieved from http://www.tandfonline.com/toc/wcrt20/ current.

Conger, R. D., Elder, G. H. Jr., Lorenz, F., Conger, K., Simons, R., Whitbeck, L., Huck, S., \& Melby, J. (1990). Linking economic hardship to marital quality and distress. Journal of Marriage and the Family, 52, 643-656. Retrieved from http://onlinelibrary. wiley.com/journal/10.1111/(ISSN)1741-3737.

Conger, R. D., Ge, X., \& Lorenz, F. O. (1994). Economic stress and marital relations. In R. D. Conger \& G. H. Elder Jr. (Eds.), Families in troubled times: Adapting to change in rural America (pp. 187-203). New York: Aldine de Gruyter.

Conger, R. D., Rueter, M. A., \& Elder, G. J. (1999). Couple resilience to economic pressure. Journal of Personality and Social Psychology, 76(1), 54-71. https://doi. org/10.1037/0022-3514.76.1.54.
Country Comparison: GDP-Per capita (PPP). (2009). CIA world factbook. Retrieved from https://www.cia.gov/library/publications/the-world-factbook/rankorder/2004rank.html.

Country Comparison: Total Fertility Rate. (2009). CIA world factbook. Retrieved from https://www.cia.gov/library/publications/theworld-factbook/rankorder/2127rank.html.

Dean, L. R., Carroll, J. S., \& Yang, C. (2007). Materialism, perceived financial problems, and marital satisfaction. Family and Consumer Sciences Research Journal, 35(3), 260-281. https://doi.org/10.11 77/1077727X06296625.

Dew, J. (2011). The association between consumer debt and the likelihood of divorce. Journal of Family and Economic Issues, 32(4), 554-565. https://doi.org/10.1007/s10834-011-9274-z.

Dew, J., Britt, S., \& Huston, S. (2012). Examining the relationship between financial issues and divorce. Family Relations, 61(4), 615-628. https://doi.org/10.1111/j.1741-3729.2012.00715.x.

Doherty, W. J., Galston, W. A., Glenn, N. D., Gottman, J., Markey, B., Markman, H. J., et al. (2002). Why marriage matters: Twenty-one conclusions from the social sciences. New York, NY: Institute for American Values.

Garðarsdóttir, R. B., \& Dittmar, H. (2012). The relationship of materialism to debt and financial well-being: The case of Iceland's perceived prosperity. Journal of Economic Psychology, 33(3), 471-481. https://doi.org/10.1016/j.joep.2011.12.008.

Gottman, J. M., \& Krokoff, L. J. (1989). Marital interaction and satisfaction: A longitudinal view. Journal of Consulting and Clinical Psychology, 57(1), 47-52. https://doi. org/10.1037/0022-006X.57.1.47.

Gudmunson, C. G., Beutler, I. F., Israelsen, C. L., McCoy, J. K., \& Hill, E. J. (2007). Linking financial strain to marital instability: Examining the roles of emotional distress and marital interaction. Journal of Family and Economic Issues, 28(3), 357-376. https:// doi.org/10.1007/s10834-007-9074-7.

Holman, T. B., Busby, D. M., Doxey, C., Klein, D. M., \& Loyer-Carlson, V. (1997). The RELATionship Evaluation (RELATE). Provo, UT: Marriage Study Consortium.

Impett, E. A., Javam, L., Le, B. M., Asyabi-Eshghi, B., \& Kogan, A. (2013). The joys of genuine giving: Approach and avoidance sacrifice motivation and authenticity. Personal Relationships, 20(4), 740-754. https://doi.org/10.1111/pere.12012.

Kashdan, T. B., \& Breen, W. E. (2007). Materialism and diminished well-being: Experiential avoidance as a mediating mechanism. Journal of Social and Clinical Psychology, 26(5), 521-539. https://doi.org/10.1521/jscp.2007.26.5.521.

Kasser, T., Cohn, S., Kanner, A. D., \& Ryan, R. M. (2007). Some costs of American corporate capitalism: A psychological exploration of value and goal conflicts. Psychological Inquiry, 18, 1-22. https:// doi.org/10.1080/10478400701386579.

Kasser, T., \& Grow Kasser, V. (2001). The dreams of people high and low in materialism. Journal of Economic Psychology, 22(6), 693-719. https://doi.org/10.1016/S0167-4870(01)00055-1.

Kasser, T., \& Ryan, R. M. (2001). Be careful what you wish for: Optimal functioning and the relative attainment of intrinsic and extrinsic goals. In P. Schmuck \& K. M. Sheldon (Eds.), Life goals and well-being: Towards a positive psychology of human striving (pp. 116-131). Goettingen: Hogrefe \& Huber Publishers.

Kline, R. B. (2016). Principles and practice of structural equation modeling. New York: Guilford Publications.

Lee, R. D. (2003). The demographic transition: Three centuries of fundamental change. Journal of Economic Perspectives, 17, 167-190.

Li, N. P., Lim, A. Y., Tsai, M., \& O, J. (2015). Too materialistic to get married and have children? PLOS ONE, 10(5), e0126543. https:// doi.org/10.1371/journal.pone.0126543.

Li, N. P., Patel, L., Balliet, D., Tov, W., \& Scollon, C. N. (2011). The incompatibility of materialism and the desire for children: Psychological insights into the fertility discrepancy among modern 
countries. Social Indicators Research, 101(3), 391-404. https:// doi.org/10.1007/s11205-010-9665-9.

Little, T. D. (2013). Longitudinal structural equation modeling. New York: Guilford Press.

Myers, D. G. (1999). Close relationships and quality of life. In D. Kahneman, E. Diener \& N. Schwarz (Eds.), Well-being: The foundations of hedonic psychology (pp. 374-391). New York: Russell Sage Foundation.

Nickerson, C., Schwarz, N., Diener, E., \& Kahneman, D. (2003). Zeroing in on the dark side of the American dream: A closer look at the negative consequences of the goal for financial success. Psychological Science, 14, 531-536. https://doi. org/10.1046/j.0956-7976.2003.psci_1461.x.

Owen, J., Rhoades, G. K., Stanley, S. M., \& Markman, H. J. (2011). The Revised Commitment Inventory: Psychometrics and use with unmarried couples. Journal of Family Issues, 32(6), 820-841. https://doi.org/10.1177/0192513X10385788.

Richins, M. L., \& Dawson, S. (1992). A consumer values orientation for materialism and its measurement: Scale development and validation. Journal of Consumer Research, 19(3), 303-316. https:// doi.org/10.1086/209304.

Rusbult, C. E. (1980). Commitment and satisfaction in romantic associations: A test of the investment model. Journal of Experimental Social Psychology, 16(2), 172-186. https://doi. org/10.1016/0022-1031(80)90007-4.

Solberg, E. G., Diener, E., \& Robinson, M. D. (2004). Why are materialists less satisfied? In T. Kasser \& A. Kanner (Eds.), Psychology and consumer culture: The struggle for a good life in a materialistic world (pp. 29-48). Washington, DC: American Psychological Association.

Stanley, S. M., \& Markman, H. J. (1992). Assessing commitment in personal relationships. Journal of Marriage and the Family, 54(3), 595-608. https://doi.org/10.2307/353245.

Stanley, S. M., Markman, H. J., \& Whitton, S. W. (2002). Communication, conflict and commitment: Insights on the foundations of relationship success from a national survey. Family Process, 41(4), 659-675. https://doi.org/10.1111/j.1545-5300.2002.00659.x.

Thomas, A., \& Sawhill, I. (2005). For love and money? The impact of family structure on family income. The Future of Children, 15(2), 57-74. https://doi.org/10.1353/foc.2005.0020.

Van Lange, P. A., Rusbult, C. E., Drigotas, S. M., Arriaga, X. B., Witcher, B. S., \& Cox, C. L. (1997b). Willingness to sacrifice in close relationships. Journal of Personality and Social Psychology, 72, 1373-1395. https://doi.org/10.1037/0022-3514.72.6.1373.

Van Lange, P. A. M., Agnew, C. R., Harinck, F., \& Steemers, G. (1997a). From game theory to real life: How social value orientation affects willingness to sacrifice in ongoing close relationships? Journal of Personality and Social Psychology, 73, 1330-1344. https://doi.org/10.1037/0022-3514.73.6.1330.

VanLaningham, J., Johnson, D. R., \& Amato, P. (2001). Marital happiness, marital duration, and the U-shaped curve: Evidence from a five-wave panel study. Social Forces, 79(4), 1313-1341. https:// doi.org/10.1353/sof.2001.0055.

Waite, L. J., \& Gallagher, M. (2000). The case for marriage: Why married people are happier, healthier, and better off financially. New York, NY: Doubleday.

Watson, J. J. (2003). The relationship of materialism to spending tendencies, saving, and debt. Journal of Economic Psychology, 24(6), 723-739. https://doi.org/10.1016/j.joep.2003.06.001.

Wieselquist, J., Rusbult, C. E., Foster, C. A., \& Agnew, C. R. (1999). Commitment, pro-relationship behavior, and trust in close relationships. Journal of Personality and Social Psychology, 77, 942-966. https://doi.org/10.1037/0022-3514.77.5.942.

Willoughby, B. J., Hall, S. S., \& Goff, S. (2015a). Marriage matters but how much? Marital centrality among young adults. The Journal of Psychology, 149(8), 796-817. https://doi.org/10.1080/002239 80.2014.979128.

Willoughby, B. J., Hall, S. S., \& Luczak, H. P. (2015b). Marital paradigms: A conceptual framework for marital attitudes, values, and beliefs. Journal of Family Issues, 36(2), 188-211. https://doi.org /10.1177/0192513X13487677.

Willoughby, B. J., Medaris, M., James, S., \& Bartholomew, K. (2015c). Changes in marital beliefs among emerging adults: Examining marital paradigms over time. Emerging Adulthood, 3(4), 219-228. https://doi.org/10.1177/2167696814563381.

Ashley B. LeBaron is a graduate student and lead research assistant in the Marriage, Family, and Human Development program at Brigham Young University. Ashley's research focuses on family finance, specifically couple finance and financial socialization. Ashley was valedictorian for the College of Family, Home, and Social Sciences graduating class of 2016 at BYU.

Heather H. Kelley is currently a Master's Student in the Marriage, Family, and Human Development program at Brigham Young University (BYU). She graduated Magna Cum Laude from BYU with a bachelor's degree in Family Studies. Her research focuses primarily on how religion impacts family relationships, and she is a lead research assistant for the American Families of Faith project.

Jason S. Carroll Ph.D. is a Professor of Marriage and Family Studies in the School of Family Life at Brigham Young University and a Fellow of the Wheatley Institution. He received his Ph.D. in Family Social Science from the University of Minnesota. Dr. Carroll is an internationally-recognized researcher and educator in the areas of marriage fragmentation, sexual intimacy, marriage readiness among young adults, the effectiveness of marriage education, and modern threats to marriage. Dr. Carroll has authored over 100 scientific articles, book chapters, and public scholarship pieces; and has presented numerous papers at national and international conferences. 